\title{
Critical Thinking Dispositions of Pre-service Turkish Language Teachers and Primary Teachers ${ }^{1}$
}

\author{
Sadet Maltepe \\ Correspondence: Sadet Maltepe, Department of Turkish Language Education, Necatibey Faculty of Education, Balikesir \\ University, Balikesir, Turkey.
}

Received: February 14, 2016 Accepted: March 7, 2016 Online Published: March 22, 2016

doi:10.11114/jets.v4i6.1353 URL: http://dx.doi.org/10.11114/jets.v4i6.1353

\begin{abstract}
The present study aimed to determine critical thinking dispositions of pre-service Turkish language and primary teachers in terms of several variables by employing descriptive survey design. The study group consisted of 215 senior students attending Turkish Language Teaching and Primary Education Departments of Necatibey Faculty of Education at Balikesir University in the 2012-2013 academic year. The data of the study was collected with The California Critical Thinking Disposition Inventory which was adapted to Turkish by Kökdemir (2003). The scale consisting of 6 sub-scales namely analyticity, open-mindedness, inquisitiveness, self-confidence, truth-seeking and systematicity has a reliability coefficient of 0.88. Coefficients of internal consistency for each subscale range between 0.61 and 0.78 . The present study found the reliability of the scale as .85 . The data were analyzed through descriptive statistics, $t$ test and one was variance analysis. It was observed in the study that the pre-service teachers had medium levels of critical thinking dispositions and that the level did not vary by their department, gender, time spent watching TV while critical thinking disposition increased as the number of books read per year went up.
\end{abstract}

Keywords: critical thinking, reading, pre-service Turkish language teacher, pre-service primary teacher

\section{Introduction}

The concept of critical thinking was previously interpreted as logical thinking that aims to guide our behaviors through philosophy. Critical thinking, which was also accepted as defining events in a correct way, later came to be defined in a broader sense. The studies carried out finally defined critical thinking as "the individual's evaluative and conscious judgment for deciding what to do and what to believe and expression of these judgments" (Euancho 2000:2; Akbiyık, 2002).

According to Ennis (1985), the primary and most important factor in teaching critical thinking skills is the teacher. Texts, workbooks that are designed, pre-organized plans can only be supplementary to instruction. However, they are insufficient in improving thinking skills alone.

The most efficient instruction is delivered by a teacher who is knowledgeable in the subject area and thinking processes, displays thinking skills and behaviors consistently, and who expects students to think systematically and carefully in writing and speaking activities. Therefore, well trained teachers have a particular role in teaching thinking skills (Akınoğlu, 2001, 27).

Both of the Turkish Curriculums (Grades 1 to 5 and 6,7,8) developed by the Ministry of National Education aim at "educating individuals who can use Turkish accurately, well and effectively, think critically and creatively, attach importance to personal and social values etc.". Setting off from the argument that "Language teaching is to some extent teaching how to think" these curriculums highlight thinking skills in a general sense and critical thinking in a more specific sense.

In the Turkish curriculums, which aim to develop students' listening, speaking, reading, writing, visual reading and visual presentation skills and to use the rules of the language accurately and effectively while performing these skills, critical thinking is defined as one of the main skills and critical (questioning) reading, listening, speaking, writing methods are included in the methods designed to improve linguistic skills. According to the curriculums, the special

\footnotetext{
${ }^{1}$ This work presented in part at International Conference on New Horizons in Education, Rome, Italy, June 2013.
} 
field competencies specified by the Ministry of National Education for Turkish Language and Primary Teachers, who also assume the task of developing students' critical thinking skills, include the competency "to use the Turkish language accurately and effectively and to act as a model in terms of communication" as well. Teachers are expected to be models in using thinking skills effectively as well as using linguistic skills. In this respect, pre-service teachers are required to graduate with high dispositions towards thinking skills in general and critical thinking skills in a more specific sense.

The present study aimed to determine the critical thinking dispositions of Turkish Language and primary teachers in terms of several variables in order to make inferences about pre-service teachers' potentials to improve their students' critical thinking skills. Within the scope of this purpose, the following questions were tried to be answered:

1) How are the critical thinking dispositions of pre-service Turkish Language and primary teachers?

2) Is there a difference between the critical thinking dispositions of pre-service Turkish Language and primary teachers?

3) Do the critical thinking dispositions of pre-service Turkish Language and primary teachers vary by gender?

4) Do the critical thinking dispositions of pre-service Turkish Language and primary teachers vary by the number of books they read in a year?

5) Do the critical thinking dispositions of pre-service Turkish Language and primary teachers vary by the daily time they spend watching TV?

\section{Method}

The study was carried out in the descriptive survey design and the study group consisted of the senior students attending the Departments of Turkish Language Teaching and Elementary Education at Balikesir University Necatibey Faculty of Education in the 2012-2013 academic year. A total of 215 students, 105 from the Turkish Language Departments and 110 from the Department of Elementary Education, participated in the study.

In order to determine critical thinking dispositions of the participants, The California Critical Thinking Disposition Inventory was employed as the data collection instrument of the study. The scale was adapted to Turkish and tested for validity and reliability by Kökdemir (2003) in Turkey. The scale is scored as a 6-point Likert type scale and consists of 51 items. Table 1 shows the names of subscales, numbers of items, minimum and maximum scores possible and the item numbers of the scale.

Table 1. Structural Properties of the California Critical Thinking Disposition Inventory

\begin{tabular}{llll}
\hline Subscale & $\begin{array}{l}\text { Number } \\
\text { of Items }\end{array}$ & $\begin{array}{l}\text { Min. and Max. Scores } \\
\text { possible }\end{array}$ & Item Numbers \\
\hline Analyticity & 10 & $10-60$ & $2,3,12,13,16,17,23,24,37,40$ \\
Open-Mindedness & 12 & $12-72$ & $5,7,15,18,22,26,33,36,41,43,45,47$ \\
Inquisitiveness & 9 & $9-54$ & $1,8,30,31,32,34,38,42,46$ \\
Self-Confidence & 7 & $7-42$ & $14,29,35,39,44,48,51$ \\
Truth-Seeking & 7 & $7-42$ & $6,11,20,25,27,28,49$ \\
Systematicity & 6 & $6-36$ & $4,9,10,19,21,50$ \\
TOTAL & 51 & $51-306$ &
\end{tabular}

Total scores obtained on the scale the structural properties of which are displayed in Table 1 were analyzed by converting into standard scores and as a result of the scoring, scores under 240 were accepted as low, those between 240 and 300 as moderate and scores over 300 were accepted as high critical thinking levels. As one can see in Table 1, the scale consists of 6 sub-scales namely analyticity, open-mindedness, inquisitiveness, self-confidence, truth seeking and systematicity. In terms of the sub-scales, total scores under 40 were accepted as low, scores between 40 and 50 as moderate and those over 50 as high. The reliability coefficient of the scale is 0.88 . Coefficients of internal consistency are between 0.61 and 0.78 for each subscale. The present study found the reliability of the scale as .85 .

The data obtained were analyzed through descriptive statistics, $t$ test and one way analysis of variance based on the sub-problems of the study. Evaluation in the test of significance was performed at the level of ".05".

\section{Results}

The findings of the study were designed within the framework of the sub-problems and are presented under five headings. 
1) How are the critical thinking dispositions of pre-service Turkish Language and primary teachers?

The first research question dealt with is "How are the critical thinking dispositions of pre-service Turkish Language and primary teachers?" In order to seek an answer to this question, the data were analyzed descriptively and the findings obtained are presented in Table 2.

Table 2. Pre-service Turkish Language and Primary teachers' Scores on critical thinking

\begin{tabular}{|c|c|c|c|c|c|c|}
\hline & Department & $\begin{array}{l}\text { Number of } \\
\text { Students } \\
(\mathrm{N})\end{array}$ & $\begin{array}{l}\text { Lowest } \\
\text { Score }\end{array}$ & $\begin{array}{l}\text { Highest } \\
\text { Score }\end{array}$ & $\begin{array}{l}\text { Arithmetic } \\
\text { mean } \\
(\bar{X})\end{array}$ & $\begin{array}{l}\text { Standard } \\
\text { deviation } \\
(\mathrm{SD})\end{array}$ \\
\hline \multirow[t]{2}{*}{ Analyticity } & Turkish & 105 & 35.00 & 58.00 & 47.28 & 5.35 \\
\hline & Primary & 110 & 34.00 & 58.00 & 47.68 & 5.54 \\
\hline \multirow[t]{2}{*}{ Open-mindedness } & Turkish & 105 & 30.00 & 59.17 & 46.34 & 6.75 \\
\hline & Primary & 110 & 33.33 & 57.50 & 44.03 & 5.75 \\
\hline \multirow[t]{2}{*}{ Inquisitiveness } & Turkish & 105 & 28.89 & 57.78 & 44.29 & 7.48 \\
\hline & Primary & 110 & 27.78 & 58.89 & 44.41 & 6.89 \\
\hline \multirow[t]{2}{*}{ Self-confidence } & Turkish & 105 & 21.43 & 54.29 & 40.43 & 6.51 \\
\hline & Primary & 110 & 20.00 & 55.71 & 41.04 & 7.09 \\
\hline \multirow[t]{2}{*}{ Truth seeking } & Turkish & 105 & 22.86 & 48.57 & 35.27 & 5.44 \\
\hline & Primary & 110 & 21.43 & 52.86 & 34.71 & 6.91 \\
\hline \multirow[t]{2}{*}{ Systematicity } & Turkish & 105 & 23.33 & 60.00 & 43.79 & 7.57 \\
\hline & Primary & 110 & 25.00 & 58.33 & 43.45 & 6.52 \\
\hline \multirow[t]{2}{*}{ TOTAL } & Turkish & 105 & 198.56 & 320.47 & 257.39 & 27.76 \\
\hline & Primary & 110 & 196.61 & 327.57 & 255.33 & 24.97 \\
\hline
\end{tabular}

It can be seen in Table 2 that pre-service Turkish language teachers have a mean of 257.39 , while it is 255.33 for pre-service primary teachers. It is stated that general critical thinking dispositions would be defined as low if the score obtained on the scale is under 240; moderate if it is between 240 and 300 and high if it is over 300 (Kökdemir 2003). Based on these results, it could be said that both pre-service Turkish Language teachers and primary teachers have moderate levels of critical thinking dispositions. As for the sub-scales, those under 40 are evaluated as low, between 40 and 50 as moderate and over 50 as high (Kökdemir 2003). Considering Table 2 in the light of this information, it could be asserted that participants from both groups have low dispositions in the "truth seeking" sub-scale concerning critical thinking; while they have moderate levels of disposition in all other sub-scales (analyticity, open-mindedness, inquisitiveness, systematicity and self-confidence).

Is there a difference between the critical thinking dispositions of pre-service Turkish Language and primary teachers?

An independent samples $t$ test was conducted in order to determine whether the department attended affects pre-service teachers' critical thinking dispositions or not.

Values from the Levene's Test, which was used to decide on the statistical tests to be conducted for the comparison of the critical thinking dispositions of pre-service Turkish language and primary teachers and several statistical values concerning the comparison of the pre-service teachers in terms of their departments are given in Table 3.

Table 3. T-test results of the Critical Thinking Dispositions of Pre-service Turkish Language and Primary Teachers in terms of their Departments

\begin{tabular}{|c|c|c|c|c|c|c|c|c|c|}
\hline & \multirow{2}{*}{ Group } & \multirow{2}{*}{$\mathrm{N}$} & \multirow{2}{*}{$\bar{X}$} & \multirow{2}{*}{ SD } & \multirow{2}{*}{ df } & \multicolumn{2}{|c|}{ Levene Stat. } & \multirow{2}{*}{$\mathrm{t}$} & \multirow{2}{*}{$\operatorname{Sig}(p)$} \\
\hline & & & & & & $\mathrm{F}$ & $\mathrm{p}$ & & \\
\hline \multirow{2}{*}{$\begin{array}{l}\text { Level of Critical } \\
\text { Thinking Disposition }\end{array}$} & Turkish & 105 & 222,00 & 23,59 & \multirow{2}{*}{213} & \multirow{2}{*}{2,155} & \multirow{2}{*}{0,144} & \multirow{2}{*}{0,797} & \multirow{2}{*}{0,426} \\
\hline & Primary & 110 & 219,59 & 20,80 & & & & & \\
\hline
\end{tabular}

Level of significance $p<, 05$

According to the Levene's Test results in Table 3, since the two sample variances of the standard scores obtained from 
the scale were homogeneous ( $\mathrm{p}=, 144>, 05)$, equivalent variance $\mathrm{t}$ test results were used among the $\mathrm{t}$ test results. These results show that critical thinking dispositions of the pre-service teachers are not significantly different in terms of the departments they attend $\left(\mathrm{t}_{(213)}=0,797 \mathrm{p}=0,426\right)$. This finding can be interpreted as there is no significant difference in favor of one group between pre-service Turkish language teachers and primary teachers in terms of their dispositions of critical thinking.

2) Do the critical thinking dispositions of pre-service Turkish Language and primary teachers vary by gender?

An independent samples t test was performed in order to evaluate the effect of gender on the pre-service teachers' critical thinking dispositions and the results are presented in Table 4.

Table 4. T-test results of the Critical Thinking Dispositions of Pre-service Turkish Language and Primary Teachers in terms of their Gender

\begin{tabular}{|c|c|c|c|c|c|c|c|c|c|}
\hline & \multirow{2}{*}{ Group } & \multirow{2}{*}{$\mathrm{N}$} & \multirow{2}{*}{$\bar{X}$} & \multirow{2}{*}{ SD } & \multirow{2}{*}{$\mathrm{df}$} & \multicolumn{2}{|c|}{ Levene Stat. } & \multirow{2}{*}{$\mathrm{t}$} & \multirow{2}{*}{$\operatorname{Sig}(p)$} \\
\hline & & & & & & $\mathrm{F}$ & $\mathrm{p}$ & & \\
\hline \multirow{2}{*}{$\begin{array}{l}\text { Level of Critical } \\
\text { Thinking Disposition }\end{array}$} & $F$ & 141 & 222,47 & 22,66 & \multirow{2}{*}{213} & \multirow{2}{*}{0,221} & \multirow{2}{*}{0,639} & \multirow{2}{*}{1,554} & \multirow{2}{*}{0,122} \\
\hline & M & 74 & 217,53 & 21,03 & & & & & \\
\hline
\end{tabular}

Level of significance $p<.05$

According to the Levene's Test results in Table 4, since the two sample variances of the standard scores obtained from the scale were homogeneous ( $\mathrm{p}=0,221>.05$ ), equivalent variance $t$ test results were used among the $t$ test results. These results show that critical thinking dispositions of the pre-service teachers do not vary significantly in terms of gender $\left(\mathrm{t}_{(213)}=1,554 ; \mathrm{p}=0,122\right)$. This finding can be interpreted as there is no significant difference in favor of any one group between the critical thinking dispositions of female pre-service teachers and male pre-service teachers.

Do the critical thinking dispositions of pre-service Turkish Language and primary teachers vary by the number of books they read in a year?

The effect of the number of books read in a year on the critical thinking dispositions of the pre-service teachers was examined through one way variance analysis. Descriptive statistics concerning the number of books the pre-service teachers read every year are presented in Table 5 and the results of the variance analysis and the LSD test are given in Table 6.

Table 5. Descriptive Statistics concerning the Number of Books the Pre-service Teachers Read in a Year

\begin{tabular}{llll}
\hline Group & $\mathrm{N}$ & Mean & SD \\
\hline None & 10 & 204,20 & 24,15 \\
$1-5$ books & 103 & 219,97 & 20,12 \\
6-11 books & 59 & 218,33 & 25,05 \\
Over 12 books & 43 & 229,88 & 19,32 \\
\hline
\end{tabular}

In Table 5, it can be seen that of the 215 pre-service teachers who participated in the study, $48 \%$ read 1-5 books in one year while $4.7 \%$ read no books. Based on this fact, it could be concluded that more than half the pre-service Turkish language and primary teachers read either no books or maximum 5 books in one year.

In a classification of individuals' reading habits, readers are divided into three groups as light readers (no more than 5 books a year), medium readers (6-11 books a year) and heavy readers (more than 12 books a year) (Yılmaz, 2004:116 cited from ALA,1978). According to this classification, of the pre-service teachers who participated in the study, 53\% can be defined as light readers, $27 \%$ as medium readers and $20 \%$ as heavy readers.

Table 6. Comparison of the Number of Books Read by the Pre-service Teachers per year and their Critical Thinking Dispositions

\begin{tabular}{|c|c|c|c|c|c|c|c|}
\hline & $\begin{array}{l}\text { Source of } \\
\text { Variance }\end{array}$ & $\begin{array}{l}\text { Sum of } \\
\text { Squares }\end{array}$ & $\mathrm{df}$ & $\begin{array}{l}\text { Mean } \\
\text { Square }\end{array}$ & $\mathrm{F}$ & $\mathrm{P}$ & $\begin{array}{l}\text { Significant } \\
\text { Differences }\end{array}$ \\
\hline $\begin{array}{l}\text { Critical } \\
\text { Thinking } \\
\text { Disposition }\end{array}$ & $\begin{array}{l}\text { Between } \\
\text { groups } \\
\text { Within groups } \\
\text { Total }\end{array}$ & $\begin{array}{l}6727,95 \\
96629,61 \\
105357,56\end{array}$ & $\begin{array}{l}3 \\
211 \\
214\end{array}$ & $\begin{array}{l}2242,65 \\
467,44\end{array}$ & 4,798 & 0,003 & $\begin{array}{l}1-2 ; \quad 1-4 ; \\
2-4 ; 3-4\end{array}$ \\
\hline
\end{tabular}

Level of significance $p<.05$ 
Test results given in Table 6 show a significant difference between the critical thinking dispositions of the pre-service teachers in terms of the number of books they read per year $(\mathrm{F}=4,798 ; \mathrm{p}=0,003)$. This finding indicates that different numbers of books read in one year have different effects on critical thinking dispositions. Moreover, the source of the difference between the number of books the pre-service teachers read per year and their critical thinking dispositions was identified with LSD test and significant differences were found between those who read no books or maximum 5 books and those who read more than 12 books per year; and between those who read maximum 5 books or 6-11 books and those who read more than 12 books per year. This finding implies that the higher the number of books read per year is, the higher the critical thinking disposition gets.

Do the critical thinking dispositions of pre-service Turkish Language and primary teachers vary by the daily time they spend watching TV?

The study finally investigated the effect of the daily time spent watching TV on the pre-service teachers' critical thinking dispositions. Descriptive statistics data regarding the time pre-service teachers spend watching TV every day are presented in Table 7 and the variance analysis results concerning the comparison of critical thinking dispositions and the time spent watching TV every day can be seen in Table 8 .

Table 7. Descriptive Statistics Concerning the Daily Time Spent Watching TV by Pre-service Teachers

\begin{tabular}{llll}
\hline Group & N & Mean & SD \\
\hline None & 47 & 225,32 & 22,45 \\
Under 2 hours & 86 & 220,34 & 21,34 \\
2 hours & 46 & 220,26 & 20,45 \\
Over 2 hours & 36 & 216,48 & 25,59 \\
\hline
\end{tabular}

Table 7 shows that $22 \%$ of the pre-service Turkish language and primary teachers who participated in the study do not watch TV at all while $40 \%$ watch TV for less than 2 hours. Based on this finding, it could be stated that most $(62 \%)$ of the pre-service Turkish language and primary teachers watch either no TV at all or for less than 2 hours every day. The TV Watching Tendencies Study carried out by RTSC with a sample group of 2.525 individuals in 21 cities found that highly educated participants aged 21-25 watch TV for more than 3 hours every day (RTÜK, 2012). Considering this finding, it can be said that most of the pre-service Turkish language and primary teachers who participated in the present study watch less TV.

Table 8. Comparison of the Pre-service Teachers' Daily TV Watching Times and Critical Thinking Dispositions

\begin{tabular}{|c|c|c|c|c|c|c|c|}
\hline & $\begin{array}{l}\text { Source of } \\
\text { Variance }\end{array}$ & $\begin{array}{l}\text { Sum of } \\
\text { Squares }\end{array}$ & $\mathrm{df}$ & $\begin{array}{l}\text { Mean } \\
\text { Square }\end{array}$ & $\mathrm{F}$ & $\mathrm{P}$ & $\begin{array}{l}\text { Significant } \\
\text { Differences }\end{array}$ \\
\hline $\begin{array}{l}\text { Critical Thinking } \\
\text { Disposition }\end{array}$ & $\begin{array}{l}\text { Between } \\
\text { groups } \\
\text { Within groups } \\
\text { Total }\end{array}$ & $\begin{array}{l}1665,15 \\
103692,41 \\
105357,56\end{array}$ & $\begin{array}{l}3 \\
211 \\
214\end{array}$ & $\begin{array}{l}555,05 \\
491,43\end{array}$ & 1,129 & 0,338 & - \\
\hline
\end{tabular}

Level of significance $\mathrm{p}<.05$

It can be seen in Table 8 that there is no significant difference between the times pre-service teachers spend watching TV every day and their critical thinking dispositions $(\mathrm{p}=0,338>0,05)$. In other words, average times the pre-service teachers spend watching TV per day do not affect their critical thinking dispositions.

\section{Discussion}

In the present study which aimed to specify critical thinking dispositions of pre-service Turkish language and primary teachers in terms of several variables, the participants in both groups were found to have moderate levels of critical thinking dispositions $(257.39 ; 255.33)$. This finding supports the results of the studies carried out by Kürüm (2002), Türnüklü and Yeşildere (2005), Çetin (2008), Özdemir (2005), Saçlı and Demirhan (2008), Şen (2009), Beşoluk and Önder'in (2010), Bağcı and Şahbaz (2012). These studies have also revealed moderate levels of critical thinking scores for pre-service teachers. On the other hand, the studies conducted by Gülveren (2007), Akar (2007), Zayif (2008) and Çetinkaya (2011) found that critical thinking levels of pre-service teachers were low.

When critical thinking dispositions of the participant pre-service Turkish language and primary teachers were evaluated in terms of the subscales; participants on both groups were found to have low levels of disposition in the "truth seeking" subscale while they had moderate levels of disposition in the subscales of analyticity, open-mindedness, inquisitiveness, 
sistematicity, and self-confidence. This finding is compatible with the findings of the studies carried out by Türknüklü and Yeşildere (2005), Zayif (2008) and Çetinkaya (2011). In the studies mentioned, the "truth seeking" subscale concerning critical thinking skills is among the subscales on which pre-service teachers had low disposition levels. This can be interpreted as the pre-service teachers have low levels of "disposition to seek the truth by evaluating different opinions" (Kökdemir, 2003).

The study concluded that critical thinking dispositions of pre-service teachers did not vary by the department they attend. Based on this, it could be stated that pre-service Turkish language and primary teachers have similar characteristics in terms of critical thinking disposition.

Critical thinking dispositions of pre-service Turkish language and primary teachers were examined in terms of their gender and no significant difference was found between the groups. Kürüm (2002), Özdemir (2005), Akar (2007), Çetin (2008), Saçlı and Demirhan (2008), Korkmaz (2009), Narin (2009), Şen (2009), Ekinci and Aybek (2010), Bağcı and Şahbaz (2012) have also concluded in their studies that gender is not a variable that causes significant differences in opinions concerning critical thinking. However, some studies have found significant differences between pre-service teachers' critical thinking dispositions and genders and showed that female students have more positive dispositions than male students. (Yıldırım, 2005; Gülveren, 2007; Zayif, 2008; Beşoluk and Önder, 2010; Çetinkaya, 2011).

The variable "the number of books read per year" was examined as to whether it affected pre-service Turkish language and primary teachers' critical thinking dispositions and first, it was found that more than half the pre-service teachers read no books or maximum 5 books per year. In addition, a significant difference was observed between the number of books read per year and critical thinking dispositions of the pre-service teachers and it has been concluded that the higher the number of books is, the greater the critical thinking dispositions get. The barriers in front of critical thinking skills include students' failure to develop concepts sufficiently and along with other barriers due to such factors as students, parents, teacher, curriculum etc, this is reported to affect the development of critical thinking skills negatively (İşlekeller, 2008). Considering the prerequisite relationship between concept development and reading skills, the influence of reading skills on the development of critical thinking skills would be understood more clearly. In addition, it is emphasized that inculcating reading habits and develop the love of reading in students and designing a curriculum that focuses on thinking are the fundamental points in teaching critical thinking skills (İpşirlioğlu, 1989). Pre-service Turkish language and primary teachers who are expected to inculcate reading habits and love of reading in children and implement learning and instruction processes that focus on thinking must themselves be good readers and effectively use thinking skills in general, critical thinking skills specifically.

Finally, the study looked into the effect of the time spent watching TV per day on critical thinking dispositions of pre-service Turkish language and primary teachers and found in the first place that most of the pre-service teachers watched either no TV at all or watched TV for less than 2 hours daily. It was concluded that no significant relationship existed between the time that pre-service teachers spent watching TV every day and their critical thinking skills; in other words, the time spent watching TV did not affect critical thinking skills.

\section{References}

Akar, Ü. (2007). Öğretmen adaylarının bilimsel süreç becerileri ve eleştirel düşünme beceri düzeyleri arasındaki ilişki. (Yayınlanmamış Yüksel Lisans Tezi). Afyonkocatepe Üniversitesi Sosyal Bilimler Enstitüsü, Afyon.

Akbıyı, C. (2002). Eleştirel düşünme eğilimleri ve akademik başarı. (Yayımlanmamış Yüksek Lisans Tezi). Hacettepe Üniversitesi Sosyal Bilimler Enstitüsü, Ankara.

Akınoğlu, O. (2001). Eleştirel düşünme becerilerini temel alan fen bilgisi öğretiminin öğrenme ürünlerine etkisi. (Yayımlanmamış Doktora Tezi). Hacettepe Üniversitesi Sosyal Bilimler Enstitüsü, Ankara.

Allen, M. (2004). Smart thinking: Skills for critical understanding and writing. Oxford: Oxford University Press.

Bağcı, H., \& Şahbaz, N. K. (2012). Türkçe öğretmeni adaylarının eleştirel düşünme becerileri üzerine bir değerlendirme. Mersin Üniversitesi Ĕ̆itim Fakültesi Dergisi, 8(1).

Beşoluk, Ş., \& Önder, İ. (2010). Öğretmen adaylarının öğrenme yaklaşımları, öğrenme stilleri ve eleştirel düşünme eğilimlerinin incelenmesi. İlköğretim Online, 9(2), 679-693.

Çetin, A. (2008). Sınıf öğretmeni adayların eleştirel düşünme gücü. (Yayınlanmamış Yüksek Lisans Tezi). Uludağ Üniversitesi Sosyal Bilimler Enstitüsü, Bursa.

Çetinkaya, Z. (2011). Türkçe öğretmen adaylarının eleştirel düşünmeye ilişkin görüşlerinin belirlenmesi. Ahi Evran Üniversitesi Kırşsehir Ĕgitim Fakültesi Dergisi, 12(3).

Ekinci, Ö., \& Aybek, B. (2010). Öğretmen adaylarının empatik ve eleştirel düşünme eğilimlerinin incelenmesi. Ilköğretim Online, 9(2), 816-827. 
Ennis, R. (1985). Goals for critical thinking curriculum. A. Costa (Ed.), Developing Minds (pp. 54-57). Alexandria, VA: Association for Supervision and Curriculum Development.

Evancho, R. S. (2000). Critical thinking skills and dispositions of the undergraduate baccalaureate nursing student. (Unpublished master's thesis), Southern Connecticut State University, Connecticut.

Gülveren, H. (2007). Eğitim fakültesi öğrencilerinin eleştirel düşünme becerileri ve bu becerileri etkileyen eleştirel düşünme faktörleri. (Yayınlanmamış Doktora Tezi). Dokuz Eylül Üniversitesi Eğitim Bilimleri Enstitüsü, İzmir.

İpşiroğlu, Z. (1989). Düşünmeyi Öğrenme ve Öğretme. İstanbul:Afa Yayınları.

İşlekeller, A. (2008). Eleştirel düşünme becerilerini temel alan türkçe ögrretiminin üstün ve normal zihin düzeyindeki ögrencilerin erişi, eleş̧tirel düşünme düzeylerine ve tutumlarına etkisi. (Yayınlanmamış Yüksek Lisans Tezi). İstanbul Üniversitesi Sosyal Bilimler Enstitüsü, İstanbul.

Kökdemir, D. (2003). Belirsizlik durumlarında karar verme ve problem çözme. (Yayınlanmamış Doktora Tezi). Ankara Üniversitesi Sosyal Bilimler Enstitüsü, Ankara.

Korkmaz, Ö. (2009) Öğretmenlerin eleştirel düşünme eğilim ve düzeyleri. Ahi Evran Üniversitesi Kırşehir Eğitim Fakültesi Dergisi. 10(1), 1-13.

Kürüm, D. (2002). Öğretmen adaylarının eleştirel düşünme gücü. (Yayınlanmamış Yüksek Lisans Tezi). Anadolu Üniversitesi Eğitim Bilimleri Enstitüsü, Eskişehir.

Narin, N. (2009). İlköğretim ikinci kademe sosyal bilgiler öğretmenlerinin eleştirel düşünme becerilerinin incelenmesi. (Yayınlanmamış Yüksek Lisans Tezi). Çukurova Üniversitesi Sosyal Bilimler Enstitüsü, Adana.

Nilson, L. B. (2003). Teaching at its best: A research based resource for college instructors. M.A: Anker Publishing Company.

Özdemir, S. M. (2005). Üniversite öğrencilerinin eleştirel düşünme becerilerinin çeşitli değişkenler açısından değerlendirilmesi. Gazi Üniversitesi Türk Eğitim Bilimleri Dergisi. 3(3), 1-17.

RTÜK. (2012). Televizyon izleme eğilimleri araştırması. Radyo Televizyon Üst Kurulu, Kamuoyu, Yayın Araştırmaları ve Ölçme Dairesi Başkanlığı. Ankara http://www.rtuk.org.tr/Icerik/DownloadRe port/13. Erişim: 10/11/2014.

Saçl1, F., \& Demirhan, G. (2008). Beden eğitimi ve spor öğretmenliği programında öğrenim gören öğrencilerin eleştirel düşünme düzeylerinin saptanması ve karşılaştırılması. Spor Bilimleri Dergisi, 19(2), 92-110.

Şen, Ü. (2009). Türkçe öğretmeni adaylarının eleştirel düşünme tutumlarının çeşitli değişkenler açısından değerlendirilmesi. Zeitschrift für die Welt der Türken Journal of World of Turks., 1(2), 69-89.

Stewart, C., \& Stoller, F. L. (1990). Critical thinking through opposing view points. TESOL Newsletter, 24(2), 4-5.

Türnüklü, E. B., \& Yeşildere, S. (2005). Türkiye'den bir profil: 11-13 yaş grubu matematik öğretmen adaylarının eleştirel düşünme eğilim ve becerileri. Ankara Üniversitesi Eğitim Bilimleri Fakültesi Dergisi. 38(2), 167-185.

Yıldırım, A. Ç. (2005). Türkçe ve türk dili ve edebiyatı öğretmenlerinin eleştirel düşünme becerilerinin incelenmesi. (Yayınlanmamış Yüksel Lisans Tezi). Zonguldak Karaelmas Üniversitesi Sosyal Bilimler Enstitüsü, Zonguldak.

Yılmaz, B. (2004). Öğrencilerin okuma ve kütüphane kullanma alışkanlıklarında ebeveynlerin duyarlılığı. Bilgi Dünyası, 5(2), 115-136.

Zayif, K. (2008). Öğretmen adaylarının eleştirel düşünme eğilimleri. (Yayınlanmamış Yüksel Lisans Tezi). Abant İzzet Baysal Üniversitesi Sosyal Bilimler Enstitüsü, Bolu.

\section{$(\mathrm{Cc}) \mathrm{BY}$}

This work is licensed under a Creative Commons Attribution 3.0 License. 